\title{
Desain Aplikasi Pengelolaan Laboratorium Komputer
}

\author{
Elly Yanuarti \\ STMIK Atma Luhur \\ J1. Jend. Sudirman, Selindung, Pangkalpinang \\ Kepulauan Bangka Belitung \\ elly@atmaluhur.ac.id
}

\begin{abstract}
Abstrak - Laboratorium komputer merupakan unit pelaksana teknis yang digunakan oleh mahasiswa untuk melaksanakan kegiatan praktikum yang bertujuan untuk menunjang pelaksanaan proses belajar mengajar agar dapat menerapkan teori dan konsep yang didapatkan diperkuliahan. Agar kegiatan praktikum dapat berjalan dengan lancar maka laboratorium komputer harus dikelola dengan baik seperti dalam pencatatan administrasi, pendataan inventaris, perawatan komputer serta pelaporan. Untuk mendukung kegiatan tersebut maka diperlukan sebuah aplikasi yang dapat mempermudah dalam pengolahan data dan pembuatan laporan. Rancangan sistem dalam penelitian ini menggunakan pendekatan sistem berorientasi objek dengan pemodelan UML. Penelitian ini menghasilkan sebuah aplikasi pengelolaan laboratorium komputer yang dapat mempermudah dalam melakukan pendataan serta dapat menghasilkan keluaran lebih mudah dan akurat.
\end{abstract}

Kata Kunci : Pengelolaan Laboratorium Komputer, Pendekatan Berorientasi Objek, UML.

\section{Pendahuluan}

Laboratorium komputer merupakan salah satu unit penting pelaksana teknis yang mendukung fungsi perguruan tinggi dibidang pelayanan dan pengembangan teknologi informasi baik yang berhubungan dengan sistem perangkat lunak, perangkat keras maupun jaringan. Laboratorium komputer berperan penting dalam meningkatkan kualitas pendidikan serta sebagai penunjang kegiatan praktikum mahasiswa dalam menerapkan teori dan konsep yang didapatkan diperkuliahan. Dalam upaya memaksimalkan fungsi dan peran laboratorium maka sangat perlu untuk memperhatikan kelengkapan sarana prasarana, pemeliharaan, pengawasan serta evaluasi terhadap pemakaian laboratorium.

STMIK Atma Luhur memiliki 1 laboratorium jaringan dan 4 laboratorium komputer dimana terdapat 40 hingga 50 unit komputer. Peralatan yang terdapat di laboratorium komputer meliputi peralatan utama dan peralatan penunjang. Peralatan utama merupakan peralatan standar yang harus ada di dalam laboratorium yang diperlukan saat kegiatan belajar mengajar berlangsung. Peralatan utama meliputi: unit komputer, meja tempat meletakan komputer, kursi duduk user, meja dan kursi dosen serta papan tulis (whiteboard). Sedangkan peralatan penunjang meliputi LCD projector, CCTV, kabel listrik, jaringan dan sebagainya. Seluruh peralatan yang berupa unit komputer dan accessoriesnya merupakan inventaris laboratorium komputer, sehingga pengadaan, pengembangan, penggunaan dan pemeliharaannya merupakan tanggung jawab bagian laboratorium komputer.

Kegiatan yang dilakukan oleh bagian laboratorium komputer antara lain melakukan inventarisasi terhadap alat dan barang-barang yang ada di laboratorium, mengatur jadwal praktikum dan membuat jadwal piket asisten. Selain itu secara berkala mengadakan pemeliharaan komputer seperti memperbaiki komponen yang rusak, mengganti komponen dengan yang baru serta jika diperlukan melakukan pemindahan komputer antar laboratorium. Bagian laboratorium komputer belum menerapkan konsep sistem informasi dimana prosedur-prosedur dari kegiatan sehari-hari masih dilakukan secara manual sehingga pemanfaatan komputer hanya sebatas untuk membuat jadwal praktikum, jadwal piket asisten laboratorium, dan mengetik laporan. Belum ada program aplikasi khusus untuk mengolah data-data tersebut.

Secara umum permasalahan yang terjadi di laboratorium komputer adalah kerusakan pada komputer baik kerusakan hardware maupun software. Kerusakan pada hardware biasanya terjadi antara lain karena kesalahan pengguna, tegangan listrik yang tidak stabil dan sebagainya. Sedangkan kerusakan software biasanya terjadi karena adanya virus komputer. Adanya kerusakan maupun penanganan kerusakan tidak pernah tercatat dengan baik. Selain itu masalah yang ada adalah tidak pastinya jumlah inventaris yang rusak ataupun hilang karena tidak dilakukan pencatatan secara rapi, tidak ada pemberian label pada barang inventaris serta kurangnya kontrol terhadap informasi keberadaan barang inventaris. Untuk itu diperlukan sebuah aplikasi pengelolaan laboratorium komputer yang dapat membantu dalam mengolah data sehingga dapat menghasilkan informasi yang lebih mudah dan akurat.

\section{TINJAUAN PUSTAKA}

\section{A. Definisi Laboratorium Komputer}

Laboratorium komputer adalah tempat riset ilmiah, eksperimen, pengukuran ataupun pelatihan ilmiah yang berhubungan dengan ilmu komputer dan memiliki beberapa komputer dalam satu jaringan untuk penggunaan oleh kalangan tertentu [1]. 


\section{B. Pendekatan Berorientasi Objek}

Pendekatan berorientasi objek adalah suatu teknik atau cara pendekatan dalam melihat permasalahan dan sistem (sistem perangkat lunak, sistem informasi, atau sistem lainnya). Pendekatan berorientasi objek akan memandang sistem yang akan dikembangkan sebagai suatu kumpulan objek yang berkorespondensi dengan objek-objek dunia nyata [2].

\section{Pemodelan UML}

Pemodelan digunakan untuk menggambarkan desain sistem. Pemodelan perangkat lunak digunakan untuk mempermudah lagkah berikutnya dari pengembangan sebuah sistem informasi sehingga lebih terencana[2].

Salah satu bentuk pemodelan adalah Unified Modeling Language (UML). Diagram UML yang digunakan untuk merancang aplikasi dalam penelitian ini antara lain : [3]

\section{Activity Diagram}

Activity diagram menggambarkan aktivitas dalam sistem yang sedang dirancang, bagaimana masing-masing aliran berawal, putusan yang mungkin terjadi, dan bagaimana mereka berakhir. Activity diagram juga menggambarkan proses paralel yang mungkin terjadi pada beberapa eksekusi. Activity diagram tidak menggambarkan behavior internal sebuah sistem tetapi lebih menggambarkan proses-proses dan jalur-jalur aktivitas dari level atas secara umum.

\section{Use Case Diagram}

Use Case Diagram adalah diagram yang menggambarkan kebutuhan sistem dari sudut pandang user dan merupakan pola perilaku sistem. Use Case Diagram digunakan untuk menggambarkan hubungan antara internal sistem dan eksternal sistem atau hubungan antara sistem dan actor.

\section{Class Diagram}

Simbol - simbol yang digunakan dalam class diagram terdiri dari :

- Class : memiliki tiga area pokok yaitu nama kelas, atribut, dan method. Nama kelas menggambarkan nama dari sebuah obyek, atribut menggambarkan batasan dari nilai yang dapat dimiliki oleh obyek, dan method menggambarkan implementasi dari layanan yang dapat dipenuhi oleh kelas.

- Association : menggambarkan mekanisme komunikasi suatu obyek dengan obyek lainnya. Atau juga dapat menggambarkan ketergantungan antar kelas.

- Agregate : menggambarkan bahwa suatu obyek secara fisik dibentuk dari obyek-obyek lain atau secara logis mengandung obyek lain.

- Multiplicity : menggambarkan banyaknya obyek yang terhubung satu dengan yang lainnya.

\section{Basis Data}

Menurut Eddy Sutanta basis data merupakan suatu kumpulan data terhubung (interrelated data) yang disimpan secara bersama-sama pada suatu media tanpa mengatap satu sama lain atau tidak perlu suatu kerangkapan data. Data disimpan dengan cara-cara tertentu sehingga mudah digunakan oleh satu atau lebih program-program aplikasi secara optimal. Data disimpan tanpa mengalami ketergantungan program yang akan menggunakannya. Selain itu data disimpan sedemikian rupa sehingga proses penambahan, pengambilan dan modifikasi data dapat dilakukan dengan mudah dan terkontrol [4].

Desain basis data adalah proses membuat desain yang akan mendukung operasional dan tujuan perusahaan. Tujuan desain basis data adalah : [5]

1. Menggambarkan relasi data antara data yang dibutuhkan oleh aplikasi dan user view.

2. Menyediakan model data yang mendukung seluruh transaksi yang diperlukan.

3. Menspesifikasikan desain dengan struktur yang sesuai dengan kebutuhan sistem.

\section{E. Tinjauan Studi}

Adapun penelitian yang berkaitan dengan pengembangan sistem informasi laboratorium diantaranya adalah :

"Sistem Informasi Manajemen Laboratorium (SIMLAB) Studi Kasus Laboratorium Progdi Sistem Informasi UMK". Penelitian ini dilakukan oleh Nanik Susanti dan Moh. Arifin. Penelitian ini menghasilkan sebuah program aplikasi yang menggunakan bahasa pemrograman PHP dan database MySQL Server [6].

"Sistem Informasi Perawatan dan Inventaris Laboratorium Pada SMK Negeri 1 Rembang Berbasis Web". Penelitian ini dilakukan oleh Hisyam Wahid Luthfi dan Berliana Kusuma Riasti. Hasil penelitian ini adalah sebuah aplikasi berbasis web[7].

\section{METODE PENELITIAN}

\section{A. Metode Pengumpulan Data}

Metode pengumpulan data yang digunakan dalam penelitian ini penulis peroleh melalui tahapan-tahapan berikut

\section{Penelitian Lapangan (Survey)}

Dalam tahap ini penulis melakukan pengamatan terkait dengan bagian laboratorium komputer serta melakukan wawancara terhadap bagian terkait sehingga diperoleh rumusan masalah.

\section{Kajian Dokumen}


Dalam tahap ini penulis mengkaji dokumen-dokumen yang diperoleh pada tahap pertama.

\section{Studi Kepustakaan}

Pada tahap ini penulis memperoleh bahan-bahan mengenai masalah yang akan dibahas dari buku-buku maupun literatur yang menunjang dalam penyelesaian masalah.

\section{B. Analisa Sistem}

Salah satu pendekatan pengembangan sistem adalah pendekatan analisa berorientasi objek. Pendekatan berorientasi objek dilengkapi dengan alat-alat teknik pengembangan sistem yang hasil akhirnya akan didapat sistem yang didefinisikan dengan baik dan jelas. Kegiatan yang dilakukan pada tahap ini adalah :

1. Menganalisa sistem yang ada, yaitu mempelajari dan mengetahui apa yang dikerjakan sistem yang ada.

2. Menspesifikasikan sistem, yaitu menspesifikasikan masukan yang digunakan, database yang ada, proses yang dilakukan dan keluaran yang dihasilkan.

Dalam melakukan analisa digunakan pemodelan UML. Salah satu diagram UML yang digunakan dalam penelitian ini adalah Activity Diagram untuk menggambarkan proses dari sistem yang sedang berjalan.

\section{Perancangan Sistem}

Tahap Perancangan Sistem adalah merancang sistem secara rinci berdasarkan hasil analisa sistem yang ada, sehingga menghasilkan model sistem baru yang diusulkan, dengan disertai rancangan database.

Alat bantu untuk memodelkan sistem yang diusulkan adalah diagram UML yaitu Use Case Diagram dan Class Diagram.

\section{HASIL DAN PEMBAHASAN}

\section{A. Activity Diagram}

Activity Diagram digunakan untuk menggambarkan proses yang terjadi. Berikut ini beberapa proses yang digambarkan antara lain :

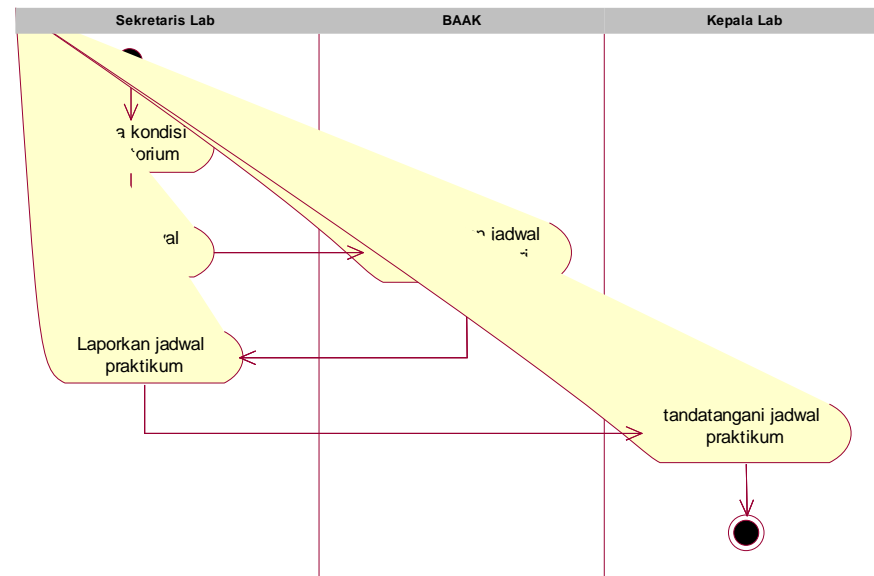

Gambar 1. Activity Diagram Proses Pembuatan Jadwal Praktikum

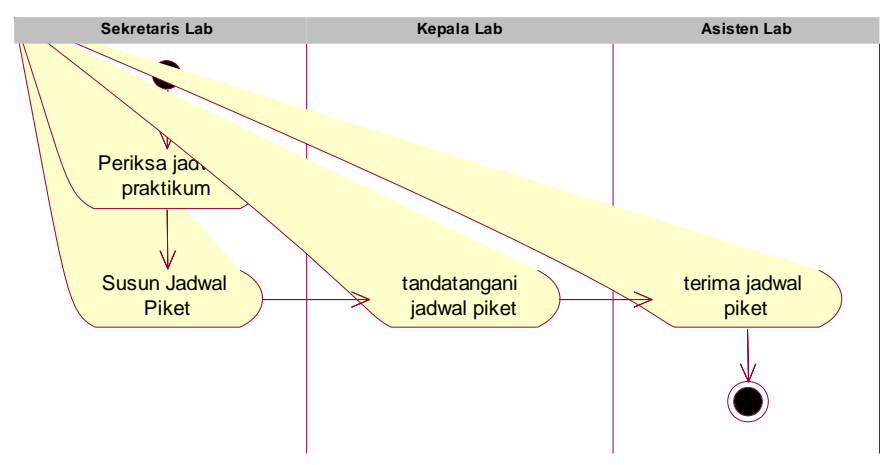

Gambar 2. Activity Diagram Proses Pembuatan Jadwal Piket Asisten Laboratorium

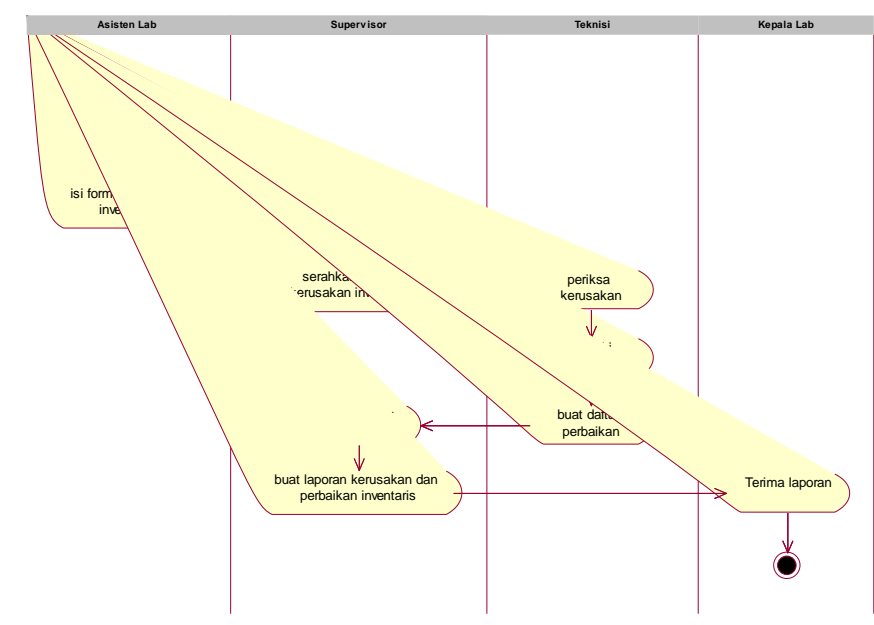

Gambar 3. Activity Diagram Proses Pembuatan Daftar Perbaikan dan Kerusakan Inventaris

\section{B. Use Case Diagram}

Use case diagram digunakan untuk menggambarkan kebutuhan dan fungsionalitas sistem dari sudut pandang user. Adapun Use Case Diagram dalam penelitian ini sebagai berikut : 


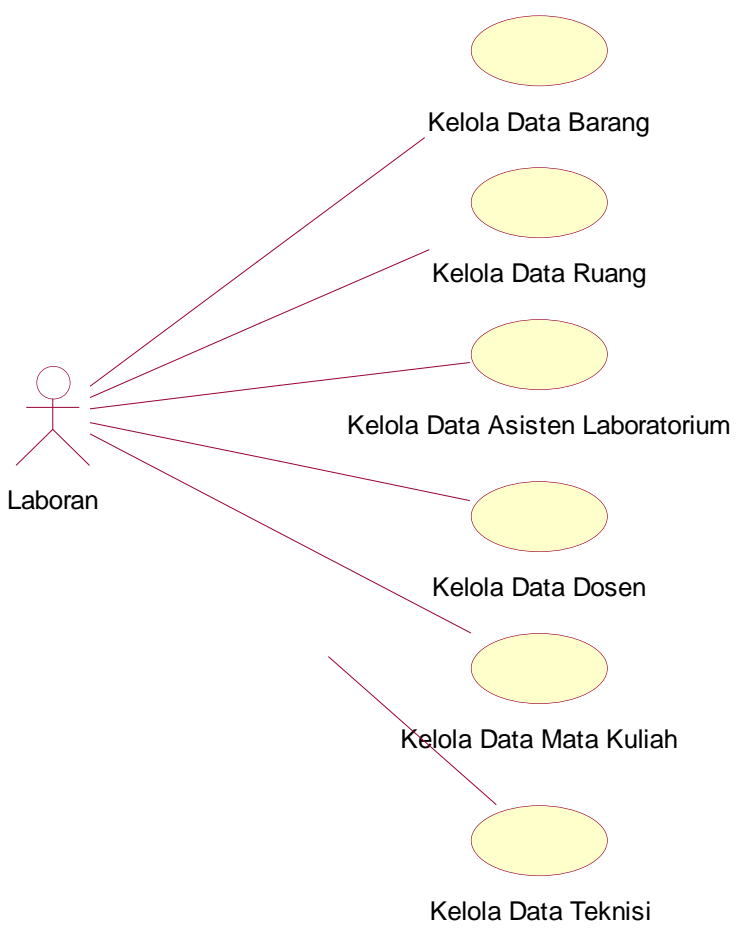

Gambar 4. Use Case Diagram Pengelolaan Data

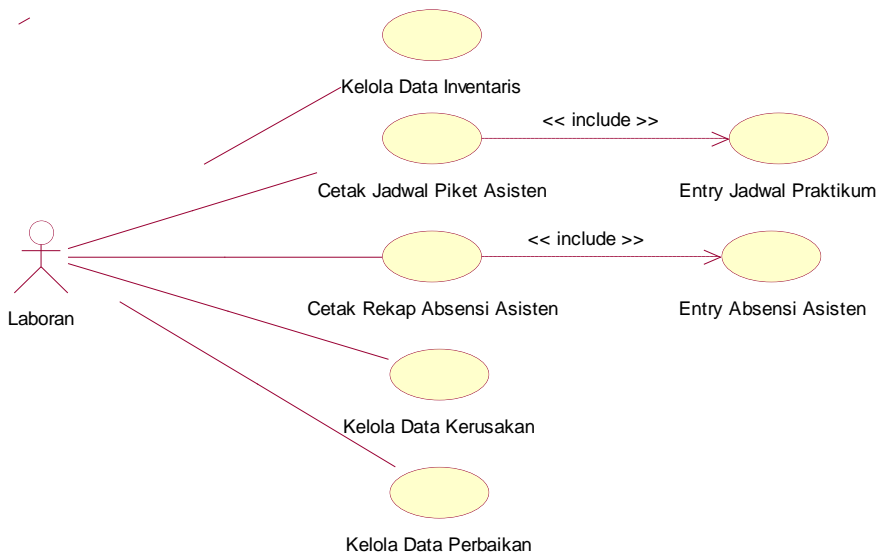

Gambar 5. Use Case Diagram Transaksi

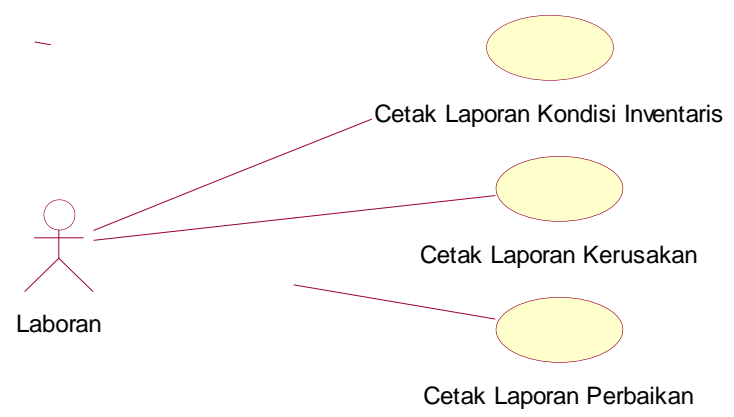

Gambar 6. Use Case Diagram Laporan

\section{Class Diagram}

Class diagram digunakan untuk membantu dalam visualisasi struktur kelas-kelas dari suatu sistem dan hubungan antar kelas dan penjelasan detail tiap kelas yang digambarkan seperti berikut :

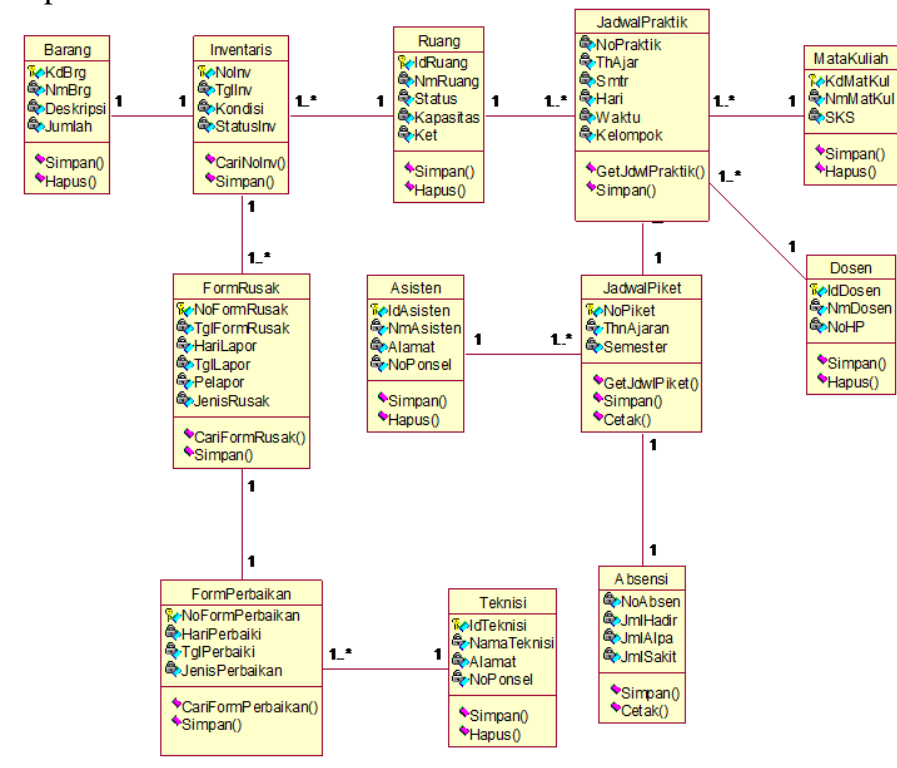

Gambar 7. Class Diagram

\section{Rancangan Basis Data}

Basis data merupakan komponen utama sistem informasi karena semua informasi untuk pengambilan keputusan berasal dari data yang ada di basis data. Dalam penelitian ini hubungan antar data dalam basis data digambar seperti berikut:

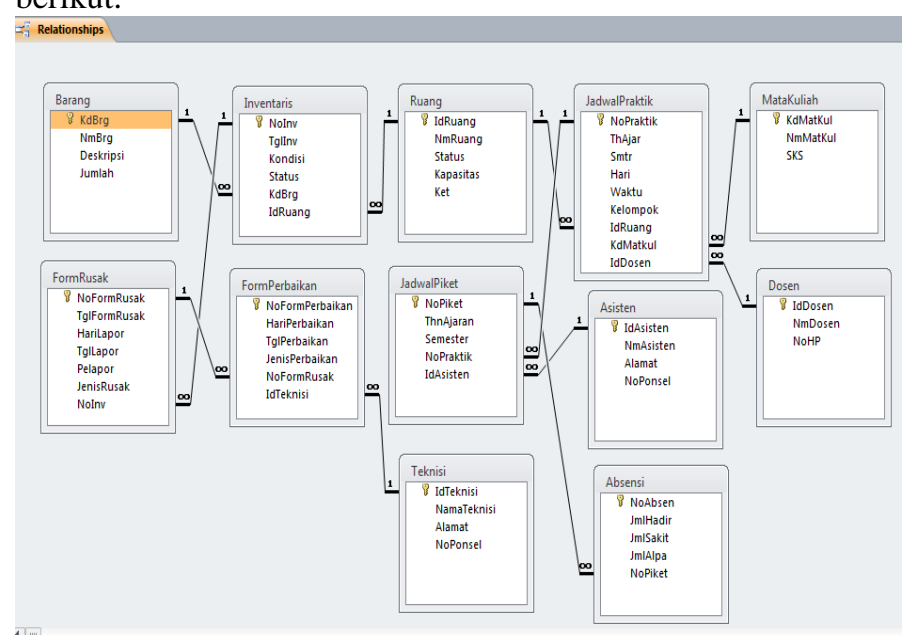

Gambar 8. Relationship Data Model 


\section{E. Rancangan AntarMuka}

Berikut ini merupakan beberapa rancangan antarmuka Aplikasi Pengelolaan Laboratorium Komputer sebagai media interaksi antara pengguna dengan sistem :

\section{Form Pengelolaan Data Ruang}

Form ini digunakan untuk menambah, mengubah dan menghapus data-data mengenai ruang laboratorium.

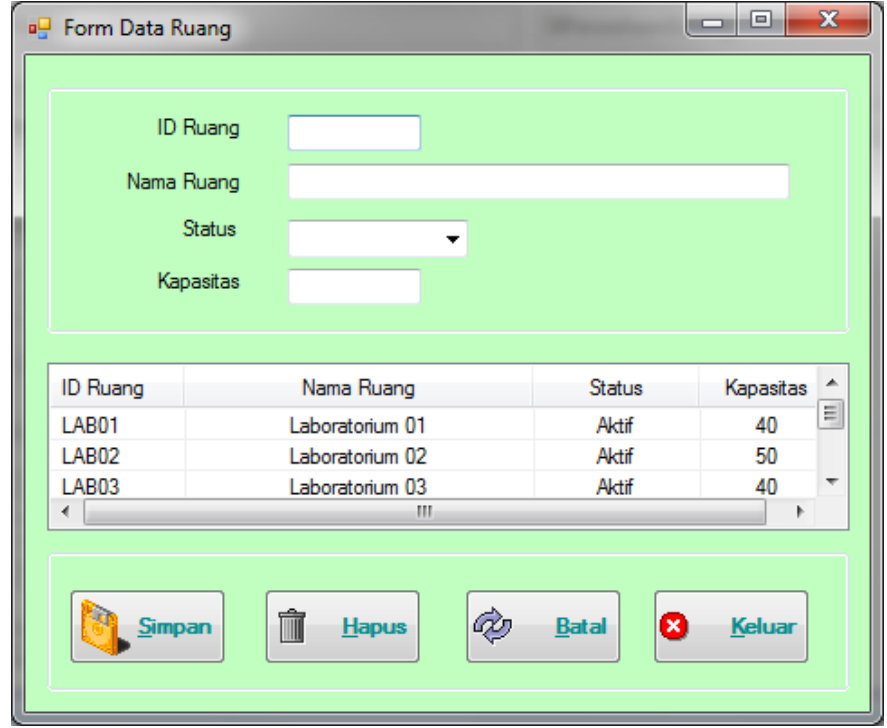

Gambar 9. Form Pengelolaan Data Ruang

\section{Form Pengelolaan Data Barang}

Form ini digunakan untuk menambah, mengubah dan menghapus data-data mengenai komputer dan peralatan yang ada di laboratorium.

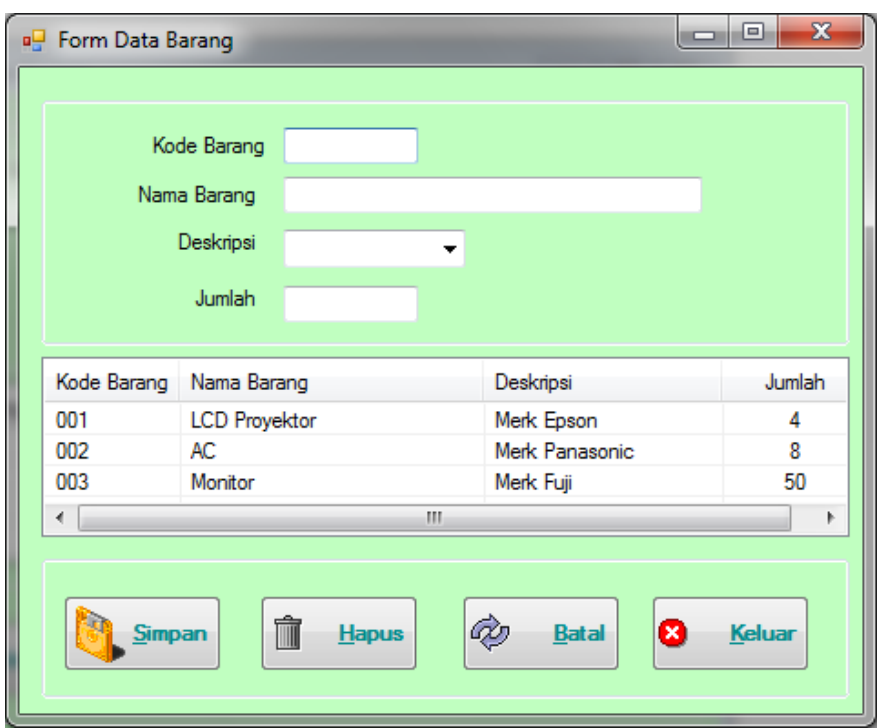

Gambar 10.Form Pengelolaan Data Barang

\section{Form Pengelolaan Data Asisten}

Form ini digunakan untuk menambah, mengubah dan menghapus data-data mengenai asisten laboratorium.

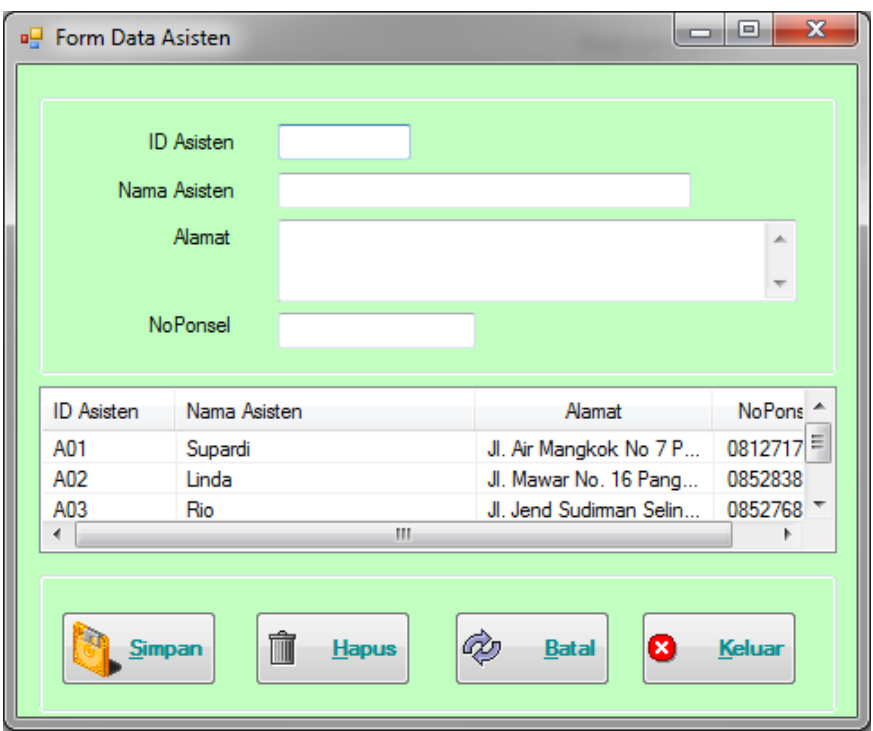

Gambar 11. Form Pengelolaan Data Asisten

\section{Form Entry Jadwal Praktikum}

Form ini digunakan untuk mengentry jadwal praktikum dimana user memilih ruang, mata kuliah dan dosen pengajar.

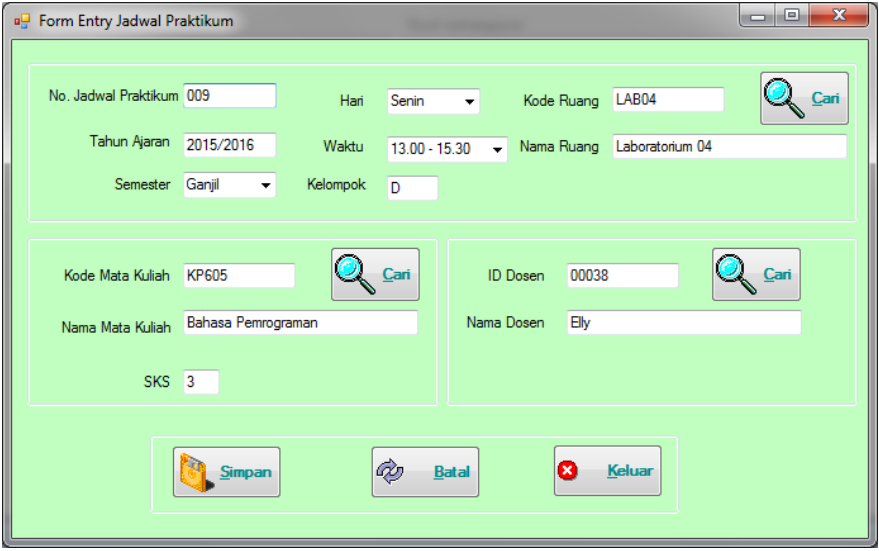

Gambar 12. Form Entry Jadwal Praktikum

\section{Form Cetak Jadwal Piket Asisten}

Form ini digunakan untuk mengentry jadwal piket asisten dimana user memilih data asisten dan jadwal praktikum sekaligus user dapat mencetak jadwal piket asisten laboratorium.. 


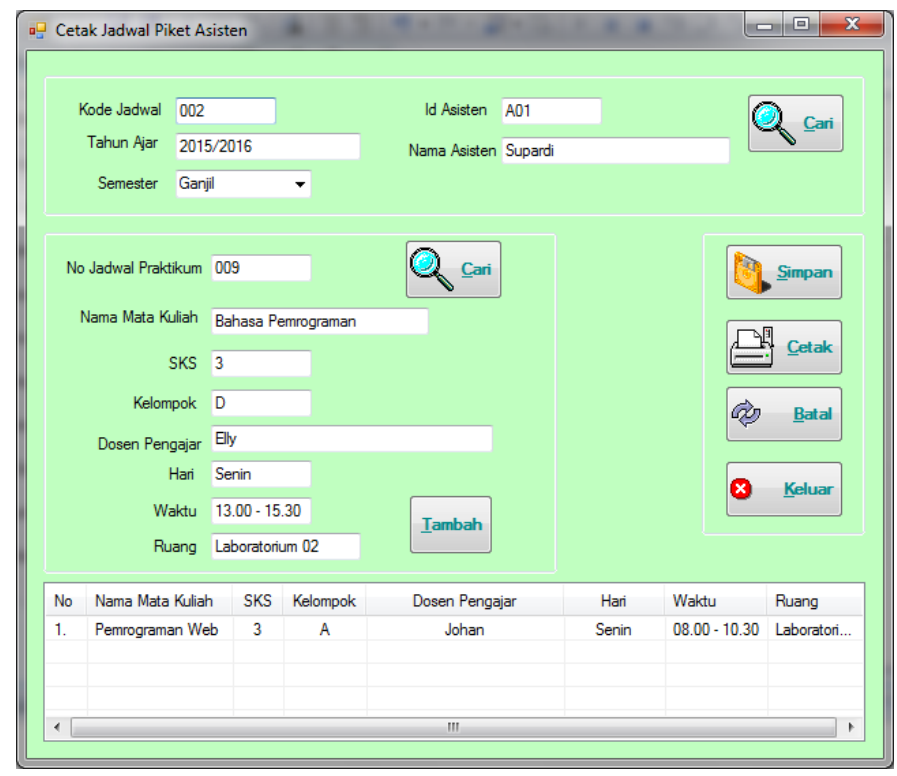

Gambar 13. Form Cetak Jadwal Piket Asisten

Output dari penginputan data piket asisten terlihat seperti gambar berikut :

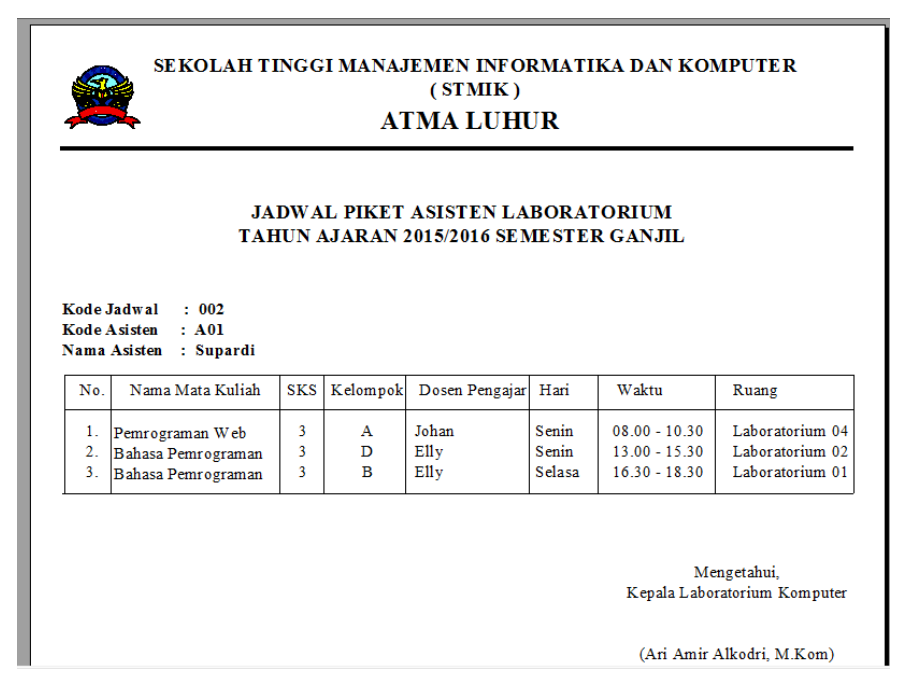

Gambar 14. Jadwal Piket Asisten

\section{Form Entry Absensi Asisten}

Form ini digunakan untuk mengentry data kehadiran asisten laboratorium di akhir semester.

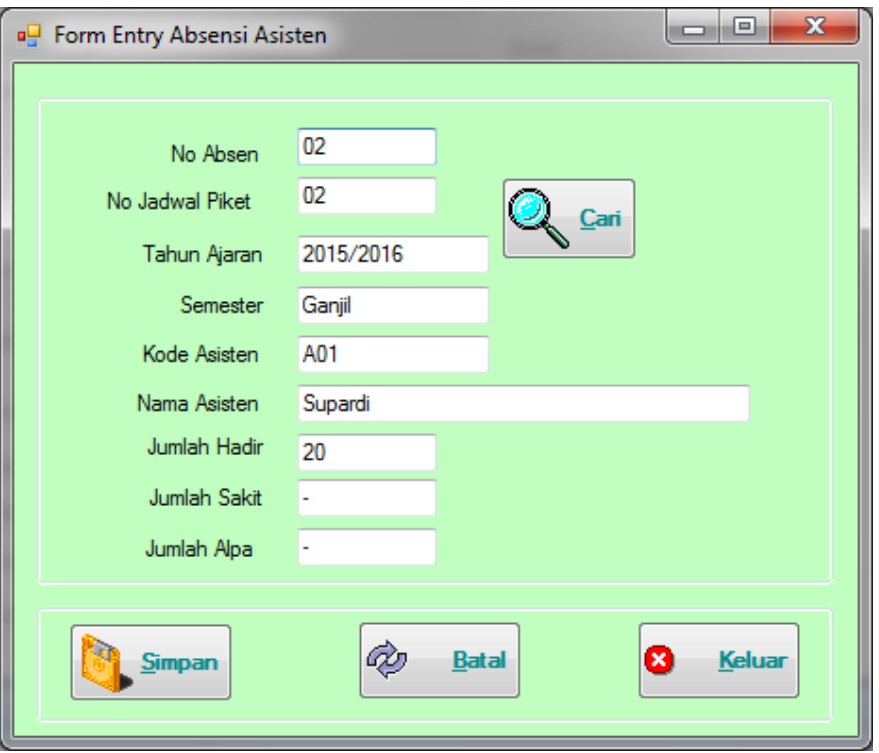

Gambar 15. Form Entry Absensi Asisten

\section{Form Pengelolaan Data Inventaris}

Form ini digunakan untuk mengelola data keadaan inventaris dan penempatannya di laboratorium.

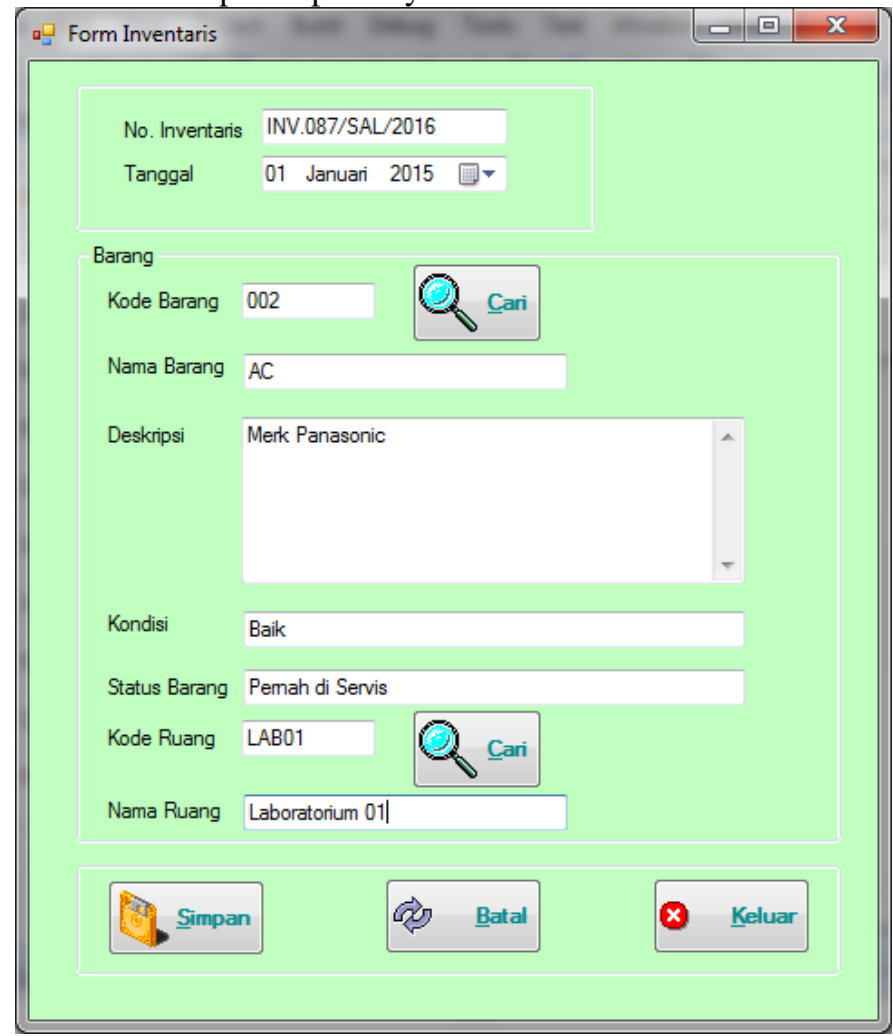

Gambar 16. Form Entry Data Inventaris 


\section{Form Entry Data Kerusakan Inventaris}

Form ini digunakan untuk mengentry data kerusakan barang inventaris.

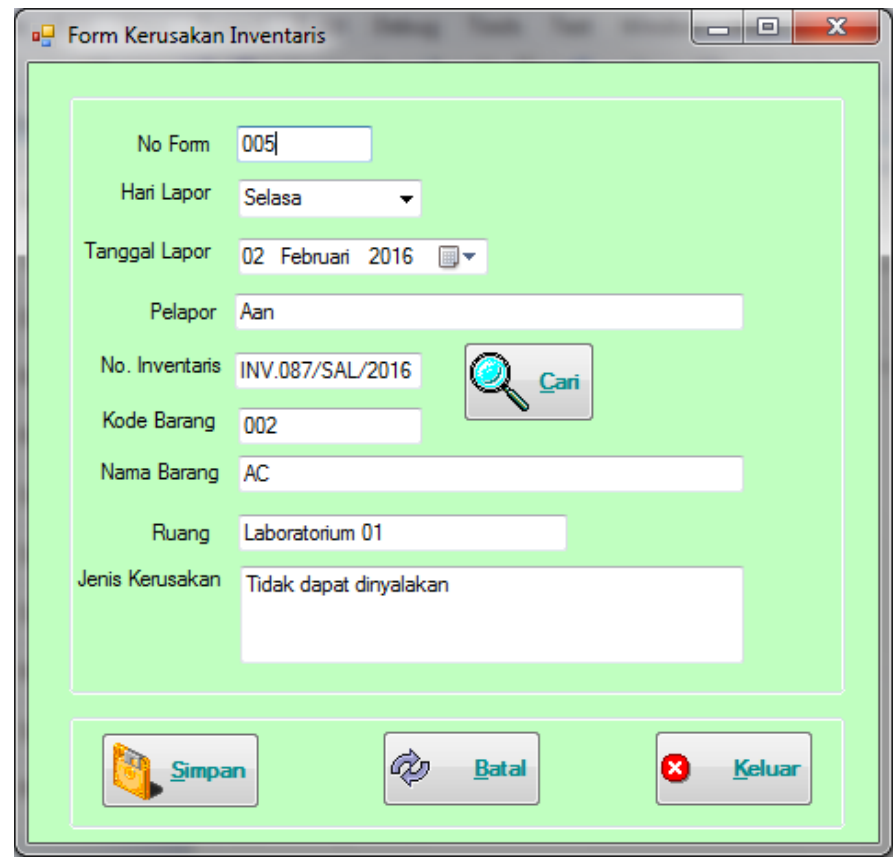

Gambar 17. Form Entry Data Kerusakan Inventaris

\section{Form Entry Data Perbaikan Inventaris}

Form ini digunakan untuk mengentry data perbaikan barang inventaris yang rusak.

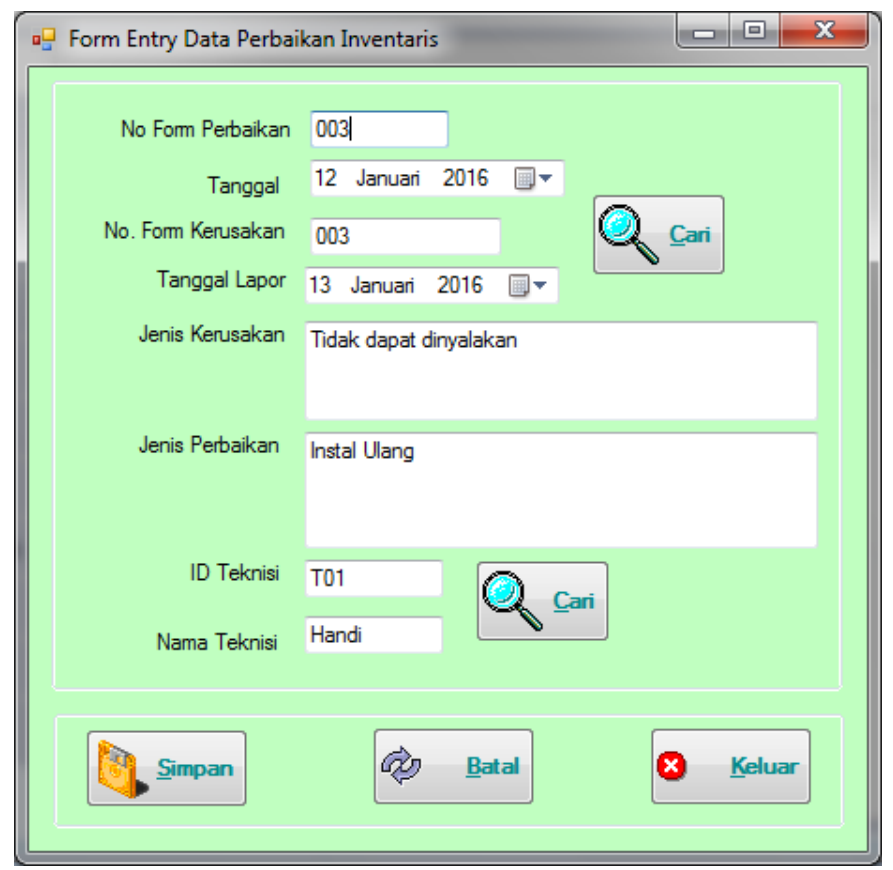

Gambar 18. Form Entry Data Perbaikan Inventaris

\section{Penutur}

Berdasarkan penelitian dan uraian diatas maka dapat ditarik kesimpulan :

1. Rancangan sistem pengelolaan laboratorium komputer ini menggunakan pemodelan UML antara lain activity diagram, use case diagram dan class diagram.

2. Rancangan aplikasi pengelolaan laboratorium komputer yang dibuat terdiri dari pengolahan data laboratorium, data barang inventaris, data asisten, jadwal praktikum, jadwal piket asisten, data kerusakan dan perbaikan komputer, rekap absensi asisten, laporan kondisi inventaris, laporan kerusakan dan perbaikan komputer.

3. Penelitian ini dibuat dalam upaya membantu mengolah data sehingga memiliki rekam jejak untuk mempermudah dalam penyampaian informasi yang lebih cepat dan akurat.

\section{DAFTAR PUSTAKA}

[1] https://id.wikipedia.org/wiki/Laboratorium_komputer $\quad$ (diakses 1 Agustus 2016).

[2] M. Shalahudin \& Rosa A.S., (2008). Analisis dan Desain Sistem Informasi. Bandung : Politeknik Telkom.

[3] Nailburg, Eric J., dan Robert A. Maksimchuck. (2002). UML For Database Design. Boston : Addison-Wesley.

[4] Sutanta, Edhy. (2011). Basis Data dalam Tinjauan Konseptual. Yogyakarta : Andi.

[5] Indrajani. (2011). Perancangan Basis Data dalam Allin1. Jakarta : Elex Media Komputindo.

[6] Susanti, Nanik dan Moh. Arifin.(2012). Sistem Informasi Manajemen Laboratorium (SIMLAB) Studi Kasus Laboratorium Progdi Sistem Informasi UMK. Majalah Ilmiah Informatika Vol. 3 No. 1.

[7] Liliana.(2012). Perancangan Sistem Informasi Inventaris di Laboratorium Komputer Jurusan Teknik Informatika Universitas " $X$ ". Prosiding SNASTIA. 